\title{
Possible bivoltine development of several bumblebee species in Europe
}

\author{
GS Potapov ${ }^{1}$, YuS Kolosova ${ }^{1}$, IN Bolotov ${ }^{1,2}$ \\ 1 Federal Centre for Integrated Arctic Research, Russian Academy of Sciences (Arkhangelsk, Russian Federation) \\ 2 Northern (Arctic) Federal University named after M.V. Lomonosov (Arkhangelsk, Russian Federation) \\ Corresponding author: Grigory Potapov (grigorij-potapov@yandex.ru)
}

Academic editor: Boris Filippov • Received 25 January 2018 • Accepted 17 February 2018 • Published 30 March 2018

Citation: Potapov GS, Kolosova YuS, Bolotov IN (2018) Possible bivoltine development of several bumblebee species in Europe. Arctic Environmental Research 18(1): 45-51. https://doi.org/10.17238/issn2541-8416.2018.18.1.45

\begin{abstract}
This article is devoted to an analysis of possible bivoltine development of several bumblebee species in Europe. This study is based on materials collected by the authors in European countries (Slovakia, France and Greece) and in the European North of Russia (Solovetsky Archipelago). Four bumblebee species were studied. They are Bombus hortorum, B. terrestris, B. pratorum and B. jonellus. Bombus hortorum was collected from south-eastern Slovakia and southern France, B. terrestris was additionally from the Isle of Crete, B. pratorum was from southern France and the Solovetsky Archipelago, and B. jonellus was collected only on the Solovetsky Archipelago. Our records reveal that several bumblebee species may have two generations per season. Bombus hortorum and B. pratorum in south-eastern Slovakia and southern France had males present in late May. Both these species have a short life cycle, so they are potentially able to produce two generations in a season. Bombus terrestis was found in January on southern France and in Late November in the Isle of Crete. Because this species has no obligate diapause, this fact may indicate bivoltine development for $B$. terrestris in the studied territories. The potential ability of $B$. jonellus to produce two generations per season was revealed during long-term research on the Solovetsky Archipelago.
\end{abstract}

\section{Keywords}

Bumblebees, two generations, Europe, climatic conditions

The study of the life cycles of different bumblebee species is an important topic in modern research into bumblebees (Stelzer et al. 2010). The study of their phenology on a global scale reveals general patterns of bumblebee life cycles in different landscape-zonal conditions.

The number of papers dedicated to this subject is relatively small. The majority of these describe the

Copyright Potapov GS et al. This is an open access article distributed under the terms of the Creative Commons Attribution License (CC-BY 4.0), which permits unrestricted use, distribution, and reproduction in any medium, provided the original author and source are credited. 
life cycle of one or two species typical for the study region (Meidell 1968, Rasmont 1985, Prŷs-Jones et al. Corbet 1987). Only a few papers summarise information on the life cycles of bumblebees. One of them is a book by Radchenko and Pesenko (1994). This work is dedicated to the biology of bees and, in one section, contains descriptions of examples of bumblebee life cycles in various climatic conditions. Also worth noting is a review by Sakagami (Sakagami 1967) describing the life cycles of bumblebees in different climatic zones.

The aim of this study was to analyse our field observations of bumblebees from different areas of Europe with a special focus on the possibility of bivoltine development of bumblebee families in certain taxa.

\section{Materials and methods}

Bumblebees from European North of Russia were studied on the Solovetsky Archipelago during longterm research 2001-2010 (Kolosova and Podbolotskaya 2010, Bolotov et al. 2013). 119 individuals were studied for the present research.

Bumblebees from European countries were collected in 2011. These came from south-eastern Slovakia, southern France and the Isle of Crete. Bumblebees were caught with an entomological net. In summary, from Europe, 55 individuals were collected and 3 were observed.

Bumblebees were identified following Løken (1973), Rasmont and Terzo (2010). In this paper, we use the taxonomic status of species according to Williams (2017). Three females of Bombus terrestris (L., 1758) from the Isle of Crete were dissected using a micro-scalpel for investigation of their crops (Alford 1975). The specimens of bumblebees are deposited in the Russian Museum of the Biodiversity Hotspots (RMBH), Federal Centre for Integrated Arctic Research, Arkhangelsk, Russia.

\section{Results}

During the field research, four bumblebees were studied. They are B. hortorum, $B$. terrestris, B. pratorum and $B$. jonellus. Bombus hortorum was collected from south-eastern Slovakia and southern France, B. terrestris was additionally from the Isle of Crete, $B$. pratorum was from southern France and the Solovetsky Archipelago, and B. jonellus was collected only on the Solovetsky Archipelago.

The full description of the studied localities and records of bumblebees are presented in Table 1.

\section{Discussion}

Our novel records reveal that several bumblebee species may have at least two generations per season. In summary, we found evidence of possible bivoltine development for the following species: $B$. hortorum (Slovakia and France), B. terrestris (Slovakia, France and Isle of Crete), B. pratorum (France

Table 1. New records of bumblebees indicating possible bivoltine development

\begin{tabular}{|c|c|c|c|c|}
\hline Species & Locality & Date & Records & Collectors \\
\hline \multirow[t]{2}{*}{$\begin{array}{l}\text { B. hortorum } \\
\text { (L., 1761) }\end{array}$} & $\begin{array}{l}\text { SE Slovakia, Vihorlatské Vrchy Region, } \\
\text { slope of the Marečková Mountain } \\
\text { [ } 48^{\circ} 49^{\prime} 40^{\prime} \mathrm{N}, 21^{\circ} 59^{\prime} 19^{\prime \prime} \mathrm{E}, 350-400 \\
\text { m alt.], oak-maple forest with herb- } \\
\text { celandine plant cover (fig. 1A) }\end{array}$ & $19-20.05 .2011$ & $\begin{array}{l}4 \text { males and } 41 \text { workers } \\
\text { collected }\end{array}$ & Bolotov \& Kolosova \\
\hline & $\begin{array}{l}\text { S France, close to La Carole Village } \\
\text { [ } 42^{\circ} 54^{\prime} 35^{\prime \prime} \mathrm{N}, 1^{\circ} 49^{\prime} 8^{\prime} \mathrm{E} \text {, approx. } 600 \\
\mathrm{~m} \text { alt.], beech forest, near travertine } \\
\text { terraces }\end{array}$ & 25.05 .2011 & 3 males collected & Bolotov \& Kolosova \\
\hline
\end{tabular}




\begin{tabular}{|c|c|c|c|c|}
\hline Species & Locality & Date & Records & Collectors \\
\hline \multirow[t]{5}{*}{$\begin{array}{l}\text { B. terrestris } \\
\text { (L., 1758) }\end{array}$} & 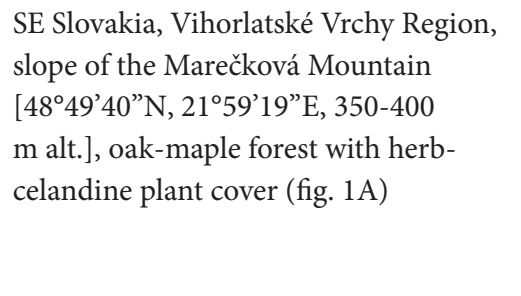 & 20.05 .2011 & $\begin{array}{l}\text { A female with specific } \\
\text { searching behaviour was } \\
\text { recorded. The female was } \\
\text { looking around a mouse } \\
\text { hole and seems to be a new } \\
\text { generation, with brilliant, } \\
\text { bright hair cover (fig. 1B) }\end{array}$ & Bolotov \& Kolosova \\
\hline & 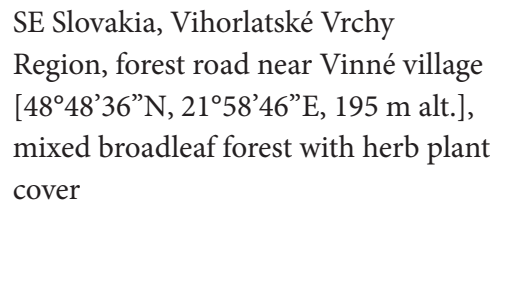 & 21.05 .2011 & $\begin{array}{l}2 \text { females with specific } \\
\text { searching behaviour were } \\
\text { recorded }^{*} \text { The females are } \\
\text { probably looking for nesting } \\
\text { sites and they appear to be a } \\
\text { new generation, with brilliant, } \\
\text { bright hair cover }\end{array}$ & Bolotov \& Kolosova \\
\hline & S France, near Toulouse, garden & 15.01 .2011 & A worker collected & $\begin{array}{l}\text { Pokrovsky \& } \\
\text { Shirokova }\end{array}$ \\
\hline & $\begin{array}{l}\text { Greece, Isle of Crete, entrance to the } \\
\text { Imbras Gorge, near café [ } 35^{\circ} 14^{\prime} 53^{\prime \prime} \\
\mathrm{N}, 24^{\circ} 10^{\prime} 3^{\prime \prime} \mathrm{E} \text {, alt. } 770 \mathrm{~m} \text { ], on the } \\
\text { flowerbed }\end{array}$ & 23.10 .2011 & A male collected & Bolotov \& Kolosova \\
\hline & $\begin{array}{l}\text { Greece, Isle of Crete, the Imbras Gorge, } \\
\text { mountain valley [ } 35^{\circ} 14^{\prime} 36^{\prime \prime} \mathrm{N}, 24^{\circ} 10^{\prime} 2^{\prime \prime} \\
\text { E, alt. } 700 \mathrm{~m} \text { ], on flowers of the } \\
\text { common ivy (Hedera helix L.) }\end{array}$ & 23.10 .2011 & $\begin{array}{l}2 \text { live and } 1 \text { dead females } \\
\text { were collected and a worker } \\
\text { was observed (fig. 1C). The } \\
\text { females were very sluggish, } \\
\text { with empty crops (dissected), } \\
\text { most likely because ivy } \\
\text { provides an imperfect nectar } \\
\text { source, but other flowering } \\
\text { plants were lacking along the } \\
\text { valley on that date (fig. 1D) }\end{array}$ & Bolotov \& Kolosova \\
\hline \multirow[t]{2}{*}{$\begin{array}{l}\text { B. pratorum } \\
\text { (L., 1761) }\end{array}$} & $\begin{array}{l}\text { S France, Pyrenees, foothills of } \\
\text { the Neouville Mountain, near the } \\
\text { boundary of Pyrenees National Park } \\
\text { [ } 42^{\circ} 48^{\prime} 05^{\prime} \mathrm{N}, 00^{\circ} 13^{\prime} 50^{\prime \prime} \mathrm{E}, 1330 \mathrm{~m} \text { alt.], } \\
\text { sparse mixed fir-beech forest with } \\
\text { juniper-grass-herb plant cover on a } \\
\text { mountain slope in a river valley (fig. } \\
\text { 1E). The early-summer phenological } \\
\text { aspect was recorded there, with } \\
\text { flowering of Anemone sp. }\end{array}$ & 26.05 .2011 & A male collected & Bolotov \& Kolosova \\
\hline & $\begin{array}{l}\text { European North of Russia, Solovetsky } \\
\text { Archipelago, Isakovo Village } \\
\text { [ } 65^{\circ} 05^{\prime} 42^{\prime \prime} \mathrm{N}, 35^{\circ} 36^{\prime} 57^{\prime} \text { E, approx. } 11 \\
\mathrm{~m} \text { alt.], grass-herb meadow near pine- } \\
\text { birch forest (fig. } 1 \mathrm{~F} \text { ). }\end{array}$ & 29.06 .2009 & A male collected & $\begin{array}{l}\text { Kolosova \& } \\
\text { Podbolotskaya }\end{array}$ \\
\hline
\end{tabular}




\begin{tabular}{|c|c|c|c|c|}
\hline Species & Locality & Date & Records & Collectors \\
\hline \multirow[t]{3}{*}{$\begin{array}{l}\text { B. jonellus } \\
\text { (Kirby, } \\
1802 \text { ) }\end{array}$} & $\begin{array}{l}\text { European North of Russia, Solovetsky } \\
\text { Archipelago, Savvatyevo Village } \\
\text { [ } 65^{\circ} 07^{\prime} 03^{\prime} \mathrm{N}, 35^{\circ} 36^{\prime} 20^{\prime} \mathrm{E} \text {, approx. } 5 \\
\mathrm{~m} \text { alt.], grass-herb meadow near pine- } \\
\text { birch forest. }\end{array}$ & 26.06 .2003 & 12 males collected & $\begin{array}{l}\text { Kolosova \& } \\
\text { Podbolotskaya }\end{array}$ \\
\hline & 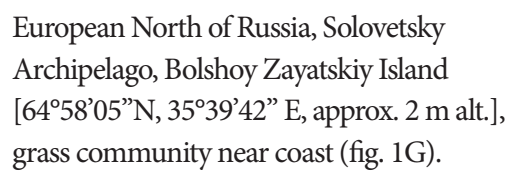 & 20.06.2009 & 20 males collected & $\begin{array}{l}\text { Kolosova \& } \\
\text { Podbolotskaya }\end{array}$ \\
\hline & $\begin{array}{l}\text { European North of Russia, Solovetsky } \\
\text { Archipelago, Isakovo and Savvatyevo } \\
\text { Villages. }\end{array}$ & 29.06.2009 & 86 males collected & $\begin{array}{l}\text { Kolosova \& } \\
\text { Podbolotskaya }\end{array}$ \\
\hline
\end{tabular}

${ }^{*}$ Visually identified as B. cf. terrestris.

and European North of Russia), and B. jonellus (European North of Russia).

In temperate latitudes, a bumblebee family typically exists only one season (Alford 1975, Goulson 2010). Bumblebee families live from spring to autumn, on average 3 to 6 months, the duration of their life depending on the different species (Goulson 2010). One reproductive generation emerged by the end of summer. From the beginning of autumn, the bumblebees from nests die, except young females of the new generation (Goulson 2010). Hence, the majority of bumblebees in temperate latitudes are characterised by an annual life cycle (Sakagami 1967). However, some species of bumblebee in temperate latitudes can transform their life cycles and are capable of producing two generation in a season (Radchenko and Pesenko 1994).

$B$. terrestris has no obligate diapause. In laboratory conditions, this species can breed throughout the year (Radchenko and Pesenko 1994). According to Rasmont et al. (2008), "In N. Europe, the phenology of Bombus terrestris is similar to that of other bumblebee species; the same is not true in Mediterranean regions, where colony foundation may occur in autumn and winter". Examples of two generations in a season for this species are known from S France, S England, Corsica and Sardinia (Stelzer et al. 2010, Rasmont 1985, Rasmont et al. 2008). According to our materials, at least bivoltine development of B. terrestris is possible in S France, near Toulouse, where a single worker of this species was collected in January. On the Isle of Crete, a male and females of $B$. terrestris were recorded in late November, which might also indicate two generations per season. Based on the observations of flowering plants and the study of bumblebee crops, we suggest that winter activity of $B$. terrestris on the Isle of Crete is not a common phenomenon, probably because limited food sources might lead to their mortality.

Both B. hortorum and B. pratorum have a short life cycle (Prŷs-Jones and Corbet), which explains the presence of males of these species in SE Slovakia and S France in late May. According to Prŷs-Jones and Corbet (1987), B. hortorum and B. pratorum may produce two generations per season in Britain, because the short life cycle allows these species "to complete a second nesting cycle in some years". Hence, it can be assumed for SE Slovakia and S France.

The ability of $B$. jonellus to produce two generations per season is well-known (Meidell 1968, PrŷsJones and Corbet 1987, Alford 1975, Alfken 1913, Douglas 1973). The two-generation ability of $B$. jonellus and also B. pratorum during the summer months is possible on the Solovetsky Islands. Entomological research on the Solovetsky Archipelago was carried out annually in the summer months 2001-2010 (re- 

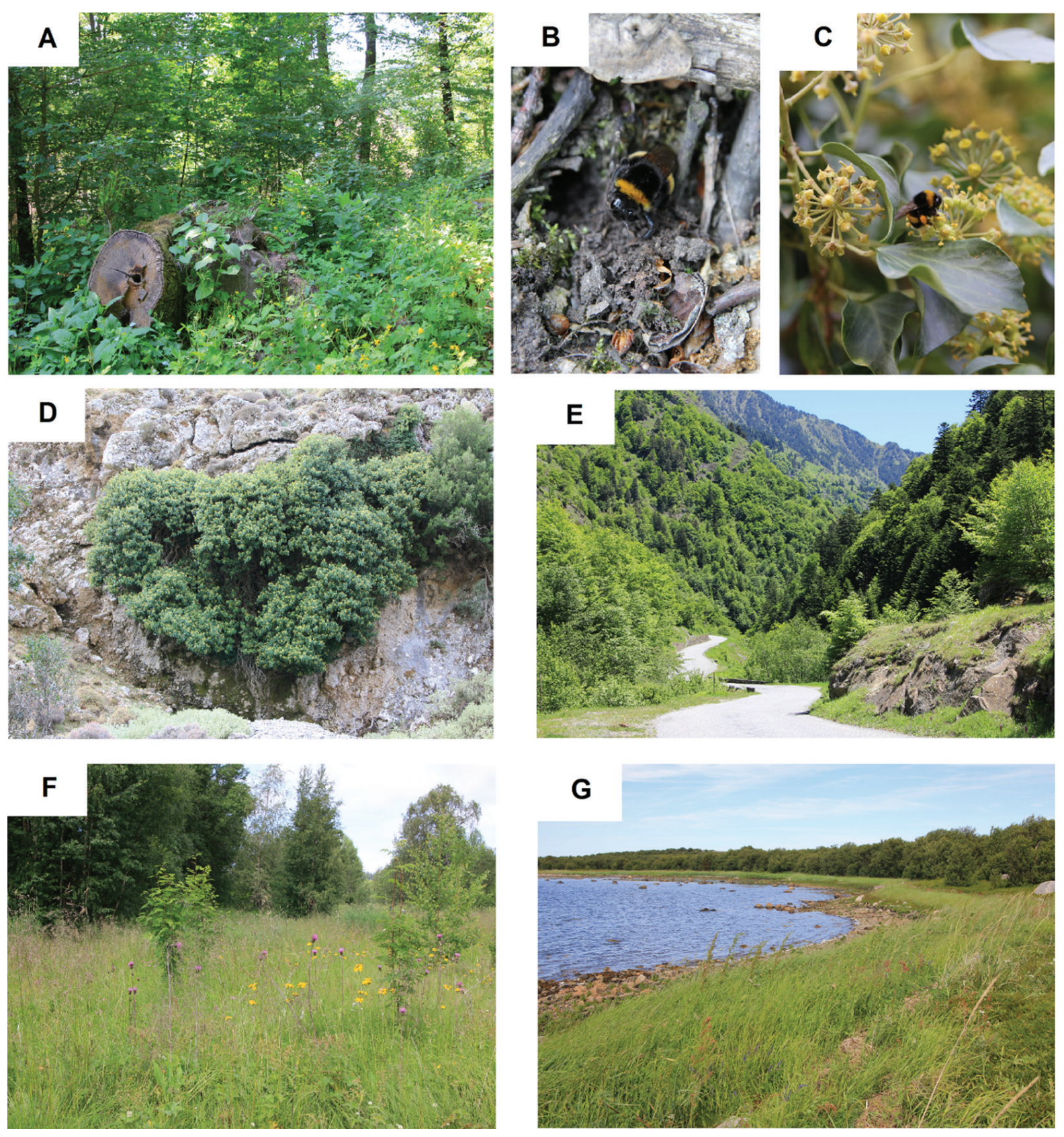

Fig. 1. Habitats and bumblebees. (A) Oak-maple forest with herb-celandine plant cover on a slope of the Marečková Mountain, 20.05.2011, Slovakia. (B) Female of B. terrestris with specific searching behaviour on a slope of the Marečková Mountain, 20.05.2011, Slovakia. (C) Worker of B. terrestris on flowers of common ivy in the Imbras Gorge, 23.10.2011, Isle of Crete. (D) Common ivy thickets on a rocky outcrop, the single available nectar source in the Imbras Gorge, 23.10.2011, Isle of Crete. (E) Sparse mixed fir-beech forest with juniper-grass-herb plant cover on the foothills of the Neouville Mountain, 26.05.2011, Pyrenees, France. (F) Grass-herb meadow near pine-birch forest in the village of Isakovo, Solovetsky Archipelago of Russia. (G) Grass community near the coast on Bolshoy Zayatskiy Island, Solovetsky Archipelago. Photos: Yu.S. Kolosova 
peated twice, for 7-10 days, each summer season: late June - early July and late July - early August) (Kolosova and Podbolotskaya 2010, Bolotov et al. 2013). The location of the Solovetsky Islands in the south-west of the White Sea leads to cool summers that are shorter than on the mainland (Shvartsman and Bolotov 2007). Overwintered females emerge here in mid-June; workers have been recorded since the end of June and reach maximum abundance by mid-July; young females and males come closer to the end of July - early August. However, in years 2003 and 2009, we observed males of B. jonellus and $B$. pratorum in late June - early July, so two generations per season can be assumed for these species on the Solovetsky Archipelago.

Finally, the problem of studying bivoltine development for bumblebee species is promising for the further research. Climate warming, which has had a global impact on bumblebees with multiple consequences (Kerr et al. 2015), can also lead to rapid shifts in the number of possible generations per season, which might have a negative influence on agricultural crops across Eurasia.

\section{References}

- Alfken JD (1913) Die Bienenfauna von Bremen. Abhandlungen des Naturwissenschaftlichen Vereins zu Bremen 22: $1-220$.

- Alford DV (1975) Bumblebees. Davis-Poynter, London, 325 pp.

- Bolotov IN, Kolosova YuS, Podbolotskaya MV, Potapov GS, Grishchenko IV (2013) Mechanism of density compensation in island bumblebee assemblages (Hymenoptera, Apidae, Bombus) and the notion of reserve compensatory species. Biology Bulletin 40(3): 318-328. https://doi.org/10.1134/ S1062359013030035

- Douglas JM (1973) Double generations of Bombus jonellus subborealis Rich. (Hym. Apidae) in an Artic summer. Entomologica Scandinavica 4: 283-284. https://doi. org/10.1163/187631273X00246

- Goulson D (2010) Bumblebees. Behaviour, Ecology and Conservation. Oxford University Press, Oxford, 330 pp.

- Kerr JT, Pindar A, Galpern P, Packer L, Potts SG, Roberts SM, Rasmont P, Schweiger O, Colla SR, Richardson LL, Wag-

\section{Acknowledgements}

The study of the bumblebee biology and ecology was performed by Grigory Potapov and supported by the Federal Agency for Scientific Organisations (no. 0409-2015-0141). Specimens of bumblebees were collected by Yulia Kolosova and supported by the Federal Agency for Scientific Organisations (no. 04092016-0022). The analysis of the global distribution of bumblebees was studied by Ivan Bolotov within a project of the Ministry of Education and Science of the Russian Federation (no. 6.2343.2017/4.6). Bumblebee species from the European North of Russia were studied by Grigory Potapov and supported by the Russian Foundation for Basic Research, RFBR (no. 16-3460035 mol_a_dk). We are especially grateful to Dr. Marina V. Podbolotskaya (1956-2014), who collected materials of bumblebees from Solovetsky Archipelago. We are indebted to Dr. Oleg S. Pokrovsky and Dr. Liudmila S. Shirokova (GET CNRS, University of Toulouse, France), who generously supplied us with material from Toulouse. Special thanks are due to Dr. $\mathrm{M}$. Copley for improving the language of the paper.

ner DL, Gall LF, Sikes DS, Pantoja A (2015) Climate change impacts on bumblebees converge across continents. Science 349(6244): 177-180. https://doi.org/10.1126/science.aaa7031

- Kolosova YuS, Podbolotskaya MV (2010) Populyatsionnaya dinamika shmeley (Hymenoptera: Apidae, Bombus Latr.) na Solovetskom arhipelage: itogi 10-letnego monitoringa [Population dynamics of bumblebees (Hymenoptera: Apidae, Bombus Latr.) on Solovetskiy Archipelago: results of 10-year monitoring]. Proceedings of the Russian Entomological Society $81(2): 135-141$.

- Løken A (1973) Studies of Scandinavian bumblebees (Hymenoptera, Apidae). Norsk Entomologisk Tidsskrift 20(1): $1-218$.

- Meidell O (1968) Bombus jonellus (Kirby) (Hym., Apidae) has two generations in a season. Norsk Entomologisk Tidsskrift 14(1): 31-32.

- Prŷs-Jones OE, Corbet SA (1987) Bumblebees. Cambridge University Press, New York, 86 pp. 
Radchenko VG, Pesenko YuA (1994) Biologiya pchel (Hymenoptera, Apoidea) [Biology of bees (Hymenoptera, Apoidea)]. Zoological Institute, Russian Academy of Scieces, St Petersburg, $351 \mathrm{pp}$.

- Rasmont P (1985) Bombus terrestris (L.) (Hymenoptera, Apidae) dans le Massif de Maures (France, Var), une generation d'hiver? Bulletin et Annales de la Société Royale Belge d'entomologie 120: 359-363.

- Rasmont P, Coppee A, Michez D, De Meulemeester T (2008) An overview of the Bombus terrestris (L. 1758) subspecies (Hymenoptera: Apidae). Annales de la Société Entomologique de France (NS) 44(1): 243-250. https://doi.org/10.1080/0037927 1.2008.10697559

- Rasmont P, Terzo M (2010) Catalogue et clé des sous-genres et espèces du genre Bombus de Belgique et du nord de la France (Hymenoptera, Apoidea). Université de Mons, Mons, 28 pp.
- Sakagami SF (1967) Specific differences in the bionomic characters of bumblebees. A comparative review. Journal of the Faculty of Science, Hokkaido University, Series 6 Zoology 20(3): 390-447.

- Stelzer RJ, Chittka L, Carlton M, Ings TC (2010) Winter active bumblebees (Bombus terrestris) achieve high foraging rates in Urban Britain. PLoS ONE 5(3): e9559. https://doi. org/10.1371/journal.pone.0009559

- Shvartsman YuG, Bolotov IN (2007) Prostranstvenno-vremennaya neodnorodnost' taezhnogo bioma v oblasti pleystotsenovykh materikovykh oledeneniy [Nature of the Solovetsky Archipelago during changing climate]. Ural Branch of RAS, Ekaterinburg, 302 pp.

- Williams PH (2017) Bombus Bumblebees of the World. London. http://www.nhm.ac.uk/research-curation/projects/bombus/index.html [accessed 22.01.2018] 